\title{
MCPH1 Gene
}

National Cancer Institute

\section{Source}

National Cancer Institute. MCPH1 Gene. NCI Thesaurus. Code C114568.

This gene plays a role in both mitotic checkpoints and brain development. 